\title{
Beyond Best Practices: Lessons from Tina Stark About the First Day of Class
}

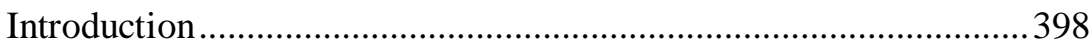

I. The Hidden Opportunities of Administrative Tasks ..............401

A. Roll Call .........................................................................401

B. Introduction of Professor and Students to Each Other ...403

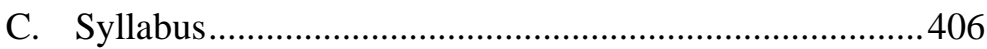

D. Other Information .......................................................410

II. Establishing a Supportive Classroom Environment................411

III. Setting Course Expectations and Standards ...........................416

IV. Preparing for the First Day...............................................421

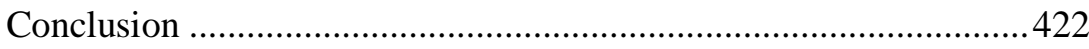

This Article reviews and expands the literature on best practices in a narrow subset - the first day of class. At the same time, it seeks to convey words of wisdom from one of the most well-known and highlyregarded legal educators: Tina Stark, a giant in transactional drafting. The first day of any law school class can be fraught with tension and nerves, even for professors. This Article presents advice from Professor Stark, supplemented with guidance from best practices research, so that professors can take advantage of the

\footnotetext{
* Associate Professor, Washburn University School of Law. This piece would not have been possible without input, encouragement, and guidance from Tina Stark; I owe her greatly. Also, thanks to Jordan Clothier for his research assistance and to Will Foster for his editorial suggestions. All references to conversations with Professor Stark and comments regarding what she said are based on my own personal experiences. Professor Stark has reviewed this piece and has given it her approval for accuracy.
} 
opportunities that the first day of class offers to set the tone for a successful semester.

\section{INTRODUCTION}

$\mathrm{T}$ his Article's purpose is twofold. First, through recounting discussions with master educator Tina Stark and reviewing best practices literature, it examines the goals and opportunities embedded in the first day of a law school class. Second, this Article identifies larger themes and effective techniques for teaching law, drawing from Professor Stark's experience and her focus on managing every aspect of her classroom environment. Often, her choices conform to previously-articulated best practices, but at times, they diverge. These divergences are intriguing and illuminate her unique perspective on teaching. Even when her approach conforms to best practices, the motivations for her actions may deviate from those typically associated with a best practice.

Tina and I first began discussing this topic in detail after her presentation at the Institute for Law Teaching and Learning conference in the summer of 2014. That program highlighted some of the most highly regarded law teachers around the country-Tina and eleven others featured in What the Best Law Teachers Do. ${ }^{1}$ Generally, during each presentation, the speaker modeled particular teaching pedagogies or styles-everything from reimagining the socratic method to using active learning exercises in rule-based classes to drawing analogies between teaching and being a traffic cop.

Tina's session focused on what many of us consider mundane: preparing for and teaching the first day of class. While many professors concentrate on making sure to take attendance, hand out syllabi, and repeat office hours three times, the best practices literature suggests that professors can use the first class to do much more. Specifically, it can set the tone for the semester, therefore affecting the remainder of the classes, which is exactly what Tina discussed and modeled at the conference. She used her presentation to show how she plans each element of the first day of class to establish the character of her classroom as a safe, collaborative environment in which she welcomes questions and respects students. One of her first day goals is to establish that her course will be intellectually rigorous - that it will demand the best of her students and of herself.

1 Michael Hunter SchwartZ, Gerald F. Hess \& Sophie M. SPARrow, What The BEST LAW TEACHERS DO (2013). 
She also confessed to going out of her way to make the class fun, even at her own expense. Finally, and most importantly, she does whatever she can to let students know that she loves teaching, looks forward to getting to know them, and wants them to succeed.

Tina spoke about the very first moments standing at the head of the classroom on the first day of class. In her presentation, she walked through a list of specific items she consciously addresses in every first class. Most helpfully, she also discussed the pedagogic and personal motivations for each item's inclusion. Through her initial interaction with students, she blends seemingly mundane administrative tasks with subtle acts or comments to influence the classroom's character. The presentation provided significant insight not only into how to use the first day of class effectively, but also into Tina's mindset as an educator who has spent years being deliberate about all aspects of her classroom.

Tina's career is illustrious to say the least. She worked as a corporate partner at Chadbourne \& Parke LLP, adjunct professor at Fordham Law School for fourteen years, then Professor in the Practice of Law at Emory University, where she served as that school's first Executive Director of its Center for Transactional Law and Practice. She also established a similar program at Boston University School of Law.

But what these biographical details don't tell you is that Tina is a world-renowned educator - a pioneer in the field of teaching transactional law and skills. ${ }^{2}$ She is revered in teaching circles of legal writing and transactional drafting professors ${ }^{3}$ and well-respected by professors who teach transactional doctrine. ${ }^{4}$ Further, as became

2 Her text, DRAFTING CONTRACTS: HOW AND Why LAWYERS Do WhAT THEY Do (2d ed. 2014), is the most widely adopted book on transactional drafting, having sold more than 20,000 copies since its initial publication in 2007. E-mail from Ellen Shapiro, Sales Support Specialist, Wolters Kluwer, to author (Aug. 13, 2015, 15:08 PST) (on file with author).

3 Outstanding Contributions to Legal Writing Education, THE BURTON AwARDS, http://www.burtonawards.com/awards-legal.html (last visited Mar. 25, 2017). Tina was the 2012 recipient of the Burton Award for Outstanding Contributions to Legal Writing Education, given by The Burton Foundation, an academic organization concentrating on legal writing.

${ }^{4}$ See, e.g., Carl J. Circo, Teaching Transactional Skills in Partnership with the Bar, 9 BERKELEY BUS. L.J. 187, 218 (2012) (referring to Tina as "a pioneer and constant advocate for transactional training"); id. at 218 n.183 ("Prof. Stark deserves special thanks not only for generously sharing her knowledge of this history, but also for her commitment to the cause of teaching transactional skills."); Jeff Lipshaw, Things You Ought To Know If You Teach Contracts, PRAWFSBLAWG (July 28, 2010), http://prawfsblawg.blogs.com 
evident at the summer 2014 conference, she is kind, eager to share her expertise with others, and eminently approachable. Naturally then, she was more than willing to talk with me about what makes an effective first day of class.

After several phone calls, Tina and I decided this topic might make an informative, useful article. We thought we should begin by reviewing existing literature on best practices for the first day of class, ${ }^{5}$ and then reflect on our own strategies for that day. Further, comparing and contrasting our approaches could be illuminating for other professors. Through our discussions, we discovered that our approaches differed, in part, because of our ages ${ }^{6}$ and different career arcs.

As we began working, however, Tina's health declined and she needed to channel her energies into herself and her family. Thus, this Article has morphed from its first iteration. Although the Article retains the best practices discussion, with Tina's blessing, it is now meant to capture Tina's specific suggestions from her presentation and her more detailed elucidation during our follow-up conversations. To the extent my own first day of class differs in an interesting or educational ${ }^{7}$ way, I have discussed those differences in the footnotes. Tina and I hope that readers will find this Article helpful in molding their own first class best practices.

The techniques explored in this Article, drawn both from research and from my conversations with Tina, give a simple blueprint of items to consider at the outset of a course, including handling administrative tasks, establishing the classroom environment, and setting course expectations and standards. These three aspects of the first day of class are not independent. Although I discuss them separately, they overlap in practice. Part I discusses administrative

/prawfsblawg/2010/07/jeff-lipshaw-things-you-ought-to-know-if-you-teach-contracts.html ("Immediately find out who Tina Stark (Emory) is, and why she is one of the most forward-thinking and innovative transactional law teachers in the country.").

5 In researching this Article, I looked not only at academic pedagogy with respect to the first class, but also to teaching strategies for general classroom management. I reviewed books and articles about teaching at the undergraduate level and, in evaluating the research, I tried to differentiate what would be appropriate for a law school population that typically was older, had diverse work experience, and graduated from colleges and universities throughout the country. Much of the research is written by professors who teach smaller classes or skills classes, so I tried to extrapolate their wisdom for a variety of law school settings and professors who have differing pedagogies and expectations of their students.

6 All that we will admit is that Tina is older.

7 Or comical. 
tasks and the way professors can use those first-class obligations to set the stage for a successful semester. Part II addresses ways professors can establish a classroom environment that will carry through the entire semester. Part III offers suggestions from the research and from Tina about establishing expectations and standards for the course. Part IV focuses on the importance of preparing for the first day of class, both mentally and logistically.

\section{I}

\section{THE HIDDEN OPPORTUNITIES OF ADMINISTRATIVE TASKS}

Many professors have likely daydreamed about strolling into an enormous lecture hall, packed with hundreds of students, who proceed to listen with rapt attention through a spellbinding hypothetical that cleverly encapsulates the policy concerns, practical stakes, and legal boundaries that will prove central to the course. After all, if Arthur Miller ${ }^{8}$ and Michael Sandel ${ }^{9}$ can do it, why can't I? For mere mortals, a more realistic goal may be to cover course policies, establish some rapport with the students, clarify how the semester will unfold and what they will be expected to do, and avoid a mutiny.

While parsing a passel of details and deadlines may seem a rather mundane introduction to yourself and your beloved course, reviewing administrative policies and the syllabus provide a template of material for the first class and a roadmap for covering that material. For many, the template and roadmap offer security by providing a clear plan for the first class, a day often fraught with tension. It is a staple of best practices for the first day and a way in which you can inject your personality, thereby giving the students a glimpse of you as a charming and brilliant scholar whose bar-tested course happened to fit nicely into their schedules.

\section{A. Roll Call}

Not surprisingly, the best practices literature lists taking attendance as part of what must be done on the first day. ${ }^{10}$ The registrar or

\footnotetext{
8 Jennifer Frey, Introducing Arthur R. Miller, NYU L. MAG., http://blogs.law.nyu.edu /magazine/2007/arthur-r-miller (last visited Mar. 25, 2017).

${ }^{9}$ Michael Sandel Involves His Students, AUDREY GRANT'S BETTER BRIDGE TEACHERS (2015), http://betterbridgeteachers.com/professional-development-michael -sandel.php.

10 BARBARA Gross DAVIS, TOOLS FOR TEACHING 21 (1993).
} 
associate dean needs to know who is in the class, who thought they dropped the class but failed to complete the appropriate paperwork, and who confused Article 9 with Art Law in the registration process. Professors can approach this task as merely administrative-passing around a sign-in sheet. Or they can use it as a tool for beginning to establish a rapport with students by reading names off of a roster and making eye contact with each student as a first step in learning students' names. In that respect, taking attendance, while certainly an administrative best practice, can also be part of the strategy to create a classroom environment conducive to interaction and learning. ${ }^{11}$

Best practices literature is not replete with attendance-taking tips, but more and more professors are using this chore as an opportunity to connect with students. Tina's approach, in conjunction with roll call, is to provide a mechanism for engaging the students on a personal level. Tina accomplishes this through "fact sheets." 12

I also have the students complete a fact sheet, in which they provide their contact information, and a few personal details, like a description of their fantasy job.

The fact sheet requests information like biographical details and an e-mail address, but, in Tina's words, this document is "a joke" given that all of the required information is easily accessible online or on the school's server. Instead, the fact sheet serves merely as a means of getting to the item of genuine interest-each student's aspirations and goals for being in the class (and law school in general). ${ }^{13}$ This insight

11 Linda S. Anderson, Incorporating Adult Learning Theory into Law School Classrooms: Small Steps Leading to Large Results, 5 APPALACHIAN J.L. 127, 148 (2006) ("For the first few weeks, take attendance, but ask students on that first day to share one thing that they think might help you remember their name. For example, Samuel may tell you he is a former sports anchorman, or Julia may explain that she is one of a set of quadruplets who are all in different law schools. In large classes, it may be useful to divide the class into groups and focus on learning one group at a time over the course of two or three weeks. After several days of taking attendance and recalling what each student has shared it will be much easier to recall names, or at least the information connected to the names. The students will see that their professor has a genuine interest in learning their names, and even if it takes months, will appreciate the effort and will feel respected.").

12 McKay Cunningham, Freshman Professor: The First Year; The First Semester; The First Day, 3 PHX L. REV. 387, 391 (2010) (“A student survey prompts students to invest themselves in your teaching and their learning. Along with the first day syllabus and reading assignments, dole out a short survey asking for each student's hometown, previous legal experience, preferred learning style, expectations for the school and for the class. When you collect the surveys at the end of the first class, you know an assortment of facts specific to each student; the student knows that you care enough to ask.").

13 Justine A. Dunlap, "I'd Just as Soon Flunk You as Look at You?" The Evolution to Humanizing in a Large Classroom, 47 WASHBURN L.J. 389, 407-08 (2008) ("[O]n the 
provides Tina with more personal information about the students and it gives her something to talk about-a way to make a connectionwith students throughout the semester. ${ }^{14}$

Although best practices literature does not address this approach to students, it is rapidly becoming a common practice as professors attempt to engage students in matters seemingly unrelated to class. For example, an open-ended question such as "Is there anything else you'd like to tell me?" listed at the bottom of a fact sheet may generate some surprising results that will provide glimpses of students' personalities and personal lives: "I have a three-year-old son with celiac disease." "I enjoy scuba diving." "This is the class I'm most worried about in law school, and I really want to succeed." Following up on these answers via e-mail can provide yet another personal connection with students during the first week of a semester. Similarly, asking students to name a book they've read recently could open up an avenue of personal connection unrelated to law school. ${ }^{15}$

\section{B. Introduction of Professor and Students to Each Other}

After roll call, it is useful for professors to take the time to introduce themselves and other key people the students will need to know-teaching assistants, administrative personnel who may be involved in collecting or returning assignments, etc. It is a critical

first day of class, I have my first-year students write information on an index card, telling me something about themselves. The information is nothing earth-shattering, the law school equivalent of name, rank, and serial number, perhaps. I always ask what, if any jobs, students have held, and what they would be doing if their law schools plans had not materialized, i.e., what was 'Plan B'? Besides satisfying my curiosity, this exercise can be valuable to me in discovering whether any students bring related work experience. Further, it communicates to the students that I am interested in who they are. Finally, it reaffirms that there is always a 'Plan B,' which is to say that life did, does, and will exist beyond the law school experience."). I ask specifically about my students' hometown because I grew up in the state where I now teach and so I can play "Pin the Dot on the Kansas Map" with the best of them.

14 Cunningham, supra note 12, at 392 ("If you know from the survey that 'Ms. Levell' has worked as a paralegal, graft a reference to her experience into your presentation. 'Ms. Levell knows as well as anyone that a motion in limine must be filed.' Or, mention to 'Mr. Thomas' before class that the 'Bulls played a good game last night,' a point of interest Mr. Thomas noted on his survey.").

15 One of my favorite semester-long exchanges involved a student in my estates and trusts class who responded that she hadn't read much lately but that she enjoyed Netflix documentaries. In my follow-up e-mail, I asked what she had seen lately and shared a few titles I enjoyed. Later in the semester when we were covering end-of-life decisions, she continued the conversation by recommending How to Die in Oregon (2011), a Netflix documentary about that state's Death with Dignity Act. 
time for the professor to introduce herself to her students and the students to introduce themselves to the professor and their classmates.

After I introduce myself, I ask students to call me by my first name. I ask their permission to call them by their first names. And I explain the pedagogical reasons for doing so.

For Tina, coming to academia from practice, it was only natural to have her students call her by her first name. After all, just three months earlier, her junior associates were doing the same thing. But the longer Tina taught, the more she saw benefits in having students call her by her first name. Tina views her upper-level course as more than a subject matter specialty; she intends that it help students transition from school to practice in every possible way. Using first names is part of her strategy.

Tina recounts that senior lawyers commonly complain that junior lawyers are uncomfortable speaking with them and with clients. Junior lawyers often do not know the appropriate tone or what is appropriate to discuss. For years as students, they called professors and their elders by honorifics. When they arrive in the working world and are given permission to use first names, junior lawyers sometimes misread the signals and inappropriately act overly-familiarforgetting that they are subordinate employees. Alternatively, senior lawyers and clients so intimidate junior lawyers that they continue to use an unduly formal tone and call their employers and clients by honorifics.

Tina hopes to have her students avoid this problem of inappropriate informality by modeling the less stilted but still professional interaction between a junior lawyer and a senior lawyer or a client. ${ }^{16}$ She knows that risks an atmosphere in which some students might cross the invisible line. But that is just fine with her, because it can lead to teaching moments. ${ }^{17}$

Many professors also use icebreakers as part of their introduction, a technique supported by best practices research as a way to get to

\footnotetext{
16 Tina's students appreciate this: "[She] treats students like junior colleagues . . . like they are part of the firm she is in." SCHWARTZ, HESS \& SPARROW, supra note 1, at 106 (alterations in original).

17 Tina often relates a story about sitting in her office at a conference table with a student. Tina needed to retrieve a piece of paper from her desk, and the ever-helpful student got up from the table and started to go behind Tina's desk to get the paper. Somewhat aghast, Tina asked, "What are you doing? You can't go behind a professor's desk." The student didn't miss a beat. He got it. "That was a learning moment, right?" When Tina tells the story, you can tell that she almost delights in the breach of decorum because it meant the student had learned what she was trying to teach.
} 
know the students and to let them get to know the professor. ${ }^{18}$ Tina's has a little twist.

I begin with an ice breaker by asking students to share something about them that most people don't know. I go first and tell a horrifically embarrassing story about my driving. ${ }^{19}$

By sharing a personal (and humbling) story, ${ }^{20}$ Tina hopes to humanize herself. She also hopes to encourage students to be similarly open about themselves, an essential element for a collaborative classroom environment where trust is paramount. Tina's use of her story accords with best practices that suggest that humanizing the professor can help enhance student learning. ${ }^{21}$ When professors share information to whatever extent comfortable, it develops rapport with the class. ${ }^{22}$

Related to class introductions, best practices research also suggests that learning students' names is crucial to developing a respectful classroom atmosphere, ${ }^{23}$ because it enhances students' feelings of

18 Maryellen Weimer, Five Things to Do on the First Day of Class, FACULTY FOCUS (Aug. 21, 2013), http://www.facultyfocus.com/articles/teaching-professor-blog/five-things -to-do-on-the-first-day-of-class.

19 To preserve the story's status as something "most people don't know," Tina wouldn't even share the story with me. Hrmph.

20 In my class, I ask students to share whatever biographical details they would like to retell but also to tell me their brush with fame. I go first and share a story that really isn't that impressive and actually makes me look a little dorky (I hid behind a pillar in an airport to sneak a photo of Jeff Probst, the host of Survivor). It sets the bar pretty low so most students don't feel bad or awkward about whatever may count as a "brush with fame" in their lives. Again, this exercise allows me to relate to my students as a person and to learn something about their life experiences.

21 See Dunlap, supra note 13, at 395-96, 400-01.

22 When I introduce myself to my legal writing students, I talk about my background and attempt to build credibility by briefly sharing about my years of clerking experience and how all I've done since law school is research and write. I also set the stage for the steep learning curve that the course presents. Law school in general, and my class in particular, is difficult; they will struggle — they all will — and that's ok. But I also don't want them to be completely paralyzed by the fear of failure. So I share my experience of being an undergraduate accounting major in college, during which the last paper I wrote (for a marketing class) featured a picture of the Pillsbury Dough Boy glued to the front cover and including such witty writing as "The Pillsbury company is rising in the ranks and really bringing in the dough." I tell them that legal writing is imminently teachable and learnable; if I can learn it, so can they, regardless of their background or comfort level with writing on Day One.

23 Paula Lustbader, Walk the Talk: Creating Learning Communities to Promote A Pedagogy of Justice, 4 SEATTLE J. FOR SOC. JUST. 613, 637 (2006); Gerald F. Hess, Heads and Hearts: The Teaching and Learning Environment in Law School, 52 J. LEGAL EDUC. 
"being valued as individuals." ${ }^{24}$ Indeed, knowing students' names without having to constantly consult a seating chart improves student learning ${ }^{25}$ because students no longer feel anonymous and able to "fade in and out without anyone's knowing or caring.",26

Tina has her students use name tents in class so that she can ensure a personal connection and interaction with them, calling them by name even on the first day. ${ }^{27}$ In the same vein as Tina's name tents, some professors may wish to create flashcards from student directory pictures to memorize student names prior to the first meeting. ${ }^{28}$ Not everyone looks precisely (or even remotely) like the student directory photos, ${ }^{29}$ so it may help to bring the flash cards for comparison. This approach also yields the added benefit of demonstrating to students that professors have been preparing to meet them. If the students are going to be invested in the class material, the professor should be invested in them.

\section{Syllabus}

With the basic introductions out of the way, the class turns to more substantive matters - one of the most important of which is going through the syllabus. Best practices literature recites the basics that

75, 88 (2002); Gerald F. Hess, Listening to Our Students: Obstructing and Enhancing Learning in Law School, 31 U.S.F. L. REV. 941, 953 (1997).

24 Anderson, supra note 11, at 140.

25 Michael T. Gibson, A Critique of Best Practices in Legal Education: Five Things All Law Professors Should Know, 42 U. BALT. L. REV. 1, 72 n.412 (2012) (citing Judith A. Sanders \& Richard L. Wiseman, The Effects of Verbal and Nonverbal Teacher Immediacy on Perceived Cognitive, Affective, and Behavioral Learning in the Multicultural Classroom, 39 COMM. EDUC. 341, 348 (1990)) (describing that a study of 952 college students in Western universities found that using student names and maintaining eye contact with them were "significantly related to behavioral learning for all four ethnic groups," (i.e., Asian, black, Hispanic, and White)).

26 Kent D. Syverud, Taking Students Seriously: A Guide for New Law Teachers, 43 J. Legal EduC. 247, 249 (1993); see also Rogelio Lasso, From the Paper Chase to the Digital Chase: Technology and the Challenge of Teaching 21st Century Law Students, 43 SANTA CLARA L. REV. 1, 44 (2002).

27 She confesses that learning and retaining student names was easier when she was younger.

28 See SCHWARTZ, HESS \& SPARROW, supra note 1, at 79. I make every effort to do this; I give myself some leeway on $100 \%$ name accuracy the first day, and hopefully the students extend that same grace. But I wager donuts that I'll have them all nailed down the second day.

29 This phenomenon is remarkable because the time between their orientation photo and the first day of class is usually around twenty-four hours. This time period is apparently marked by a compulsive desire to shave, to rapidly grow or dye hair, and to acquire an impressive collection of headwear. 
should be included in any well-drafted syllabus: where and when the class meets, course goals, the assigned text, assignment due dates, class policies, etc. ${ }^{30}$ Discussing each of these topics provides professors with an opportunity to do more than merely reiterate what is in the syllabus. It opens the door to discussing salient course issues.

The course syllabus lends itself to a discussion of a wide variety of administrative topics relevant to the class. ${ }^{31}$ Even if you post the syllabus online, bringing hard copies to class creates an opportunity to engage each student personally as you distribute the materials. In addition to logistical information including where and when the class meets and which textbooks are required, ${ }^{32}$ the syllabus should state the professor's office hours. Discussing this often-overlooked portion of the syllabus permits a professor to demonstrate an interest in students' learning and other goals.

For the less-seasoned law professor, the syllabus and administrative policies serve as a handy coverage outline and can even be a safety blanket, especially for those averse to scripting their class notes in great detail. This template acts like an introduction to an oral argument - the first several lines are preplanned, easing the professor into the role of the authority figure in the classroom.

Tina embraces the tasks of reciting the administrative edicts and sorting through the course schedule and policies, but also emphasizes her availability and interest in students:

I review the content of the course syllabus, highlighting information about what the course will cover, conveying my expectations for student learning, and explaining methods of assessment. I specifically mention my office hours and invite students to use them as needed.

Accordingly, Tina delivers the necessary information, but also opens the door for individual communication with her students. Her availability and willingness to help are one of the key themes of the first day of class.

30 Terrence Leas, The Course Syllabus: Legal Status and Implications for Practitioners, 177 EDUC. L. REP. 771, 775-78 (2003); see also, e.g., Jeanne M. Slattery \& Janet F. Carlson, Preparing an Effective Syllabus: Current Best Practices, 53 C. TEACHING 159 (2005); Jay Parkes \& Mary B. Harris, The Purposes of a Syllabus, 50 C. TEACHING 55 (2002).

31 DAVIS, supra note 10, at 22.

32 Id. ("Bring copies of the required texts to the first class meeting. Know which stores besides the campus bookstore stock the texts. Are used copies available? Is the textbook on reserve in the library?"). 
But Tina goes beyond merely stating when her office hours are. She explicitly makes herself available to students in ways beyond simply helping them with the course. Tina encourages her students to reach out to her about course selection questions, job search advice, and even résumé preparation assistance.

Professors adopting Tina's advice here should be mindful of the suggestion from best practices research about drawing clear lines regarding appropriate communication to prevent uncomfortable exchanges with students down the line. ${ }^{33} \mathrm{~A}$ thorough syllabus specifies acceptable (or, perhaps more importantly, unacceptable) ways for students to contact the professor-via phone, e-mail, text messaging, Snapchat, etc.

In light of the increasing emphasis on assessment in legal education, best practices literature urges professors to highlight the important course goals defined by the syllabus, major assignments for the semester, and any course specific policies, including how students will be graded. ${ }^{34}$ Tina makes a special point of addressing assessment during her walk-through of the syllabus because her class differs from most other law school courses.

In discussing the grading procedures outlined in the syllabus, I explain that students will be graded collaboratively.

The collaborative nature of Tina's classroom is a crucial element to her course, and so collaboration - both the logistics and the benefitsserves as a running theme throughout the first day. Starting with the syllabus, Tina wants students to be aware of the upcoming collaborative projects. Knowing that some students recoil from team grading, Tina offers them a chance (nicely) to consider attending a different section of the course. But she also reminds them that their friends in business school work, and are graded, in teams all the time. Thus, she hints not too subtly to her students that if their future clients are learning to work in teams, so too should they. Occasionally, students choose a different section. Most remain. ${ }^{35}$

Although reiterating the deadlines in the syllabus is seemingly administrative, it can serve to emphasize the necessity of project and

33 See, e.g., Susan J. Becker, Advice for the New Law Professor: A View from the Trenches, 42 J. LEGAL EDUC. 432, 445 (1992).

34 See Matthew C. Cordon, Task Mastery in Legal Research Instruction, 103 L. LIBR. J. 395, 411 (2011).

35 And they enjoy the collaborative experience. SCHWARTZ, HESS \& SPARROw, supra note 1 , at 219-20. 
time management in law school and law practice. ${ }^{36}$ To that end, perusing the syllabus together and noting important deadlines and due dates can help students plan their semester. Providing students with a calendar of significant due dates lends itself to a conversation about time allocation for each project. It may even help to have students work backwards to ensure they have enough time to complete each one satisfactorily. In addition to helping students manage their time, this conversation allows professors to model effective planning and project management.

Adventurous professors may want to do more than merely review their prepared syllabus with the class. For example, they could use it to experiment with innovative approaches to syllabus design. Some professors collaborate with students on portions of the syllabus, ${ }^{37}$ such as course coverage or the relative weight of various assignments or the penalty for late papers. ${ }^{38}$ Other professors ask the students to identify questions about the course for the professor. ${ }^{39}$ By tackling the syllabus in a unique approach, the professor turns something seemingly ordinary and mundane into an opportunity to build on the professor-student relationship.

\footnotetext{
36 Christine P. Bartholomew, Time: An Empirical Analysis of Law Student Time Management Deficiencies, 81 U. CIN. L. REV. 897, 901 (2013) ("Starting time management training early helps law students to survive and thrive both in school and after graduation."); Gary Bauer, Addressing the Needs of Solo/Small Firm Practitioners Through Law School Based Programs to Reduce Stress in Practice - Several Approaches, 6 T.M. CoOley J. PraC. \& CliniCAL L. 1, 18 (2003) ("Good time-management skills are essential for success in life and particularly important for someone who practices law.").

37 Gerald F. Hess, Collaborative Course Design: Not My Course, Not Their Course, but Our Course, 47 WASHBURN L.J. 367, 380-84 (2008) (describing the process of collaborative syllabus design, which allows student input on goals, teaching and learning methods, student and teacher roles and responsibilities, and evaluation).

38 Nancy L. Schultz, Building a Professional Community, 11 GeO. J. Legal ETHICS 1, 7 (1997) ("On the first day of class, I presented my students with a draft contract, which included the proposed schedule for the semester, the proposed assignments, and some proposed behavioral rules governing the timely submission of assignments and similar issues."); $i d$. at 7-8 (explaining that after students proffered proposed redrafts of the contract, the professor created a final version of the contract incorporating student changes, and every class member, including the professor, signed it as the governing document for the semester).

39 Hess, supra note 37 , at 386 .
} 


\section{Other Information}

The syllabus will likely also contain school or university policies about attendance ${ }^{40}$ and academic misconduct. ${ }^{41}$ Although most law students will have been introduced to general policies already, some important policies like attendance and participation expectations are often unique to the individual course. Other school-wide policies may be particularly applicable in a given class, like the honor code and how it applies specifically to permissible (and impermissible) collaboration. Some of this discussion, however, may be reserved for first-year courses; upper-level law students will likely be familiar with the basic governing policies.

For Tina, this discussion includes particular information about what collaboration is appropriate (and expected) through the semester and what collaboration is not permitted. To that end, her students sign an Honor Code acknowledgment - that getting or giving help, except as permitted, is a violation of the Honor Code.

Another widely-encouraged administrative function for the first day, if not included in the syllabus, is to give students information about where they can get various kinds of assistance with the course, and with law school in general. ${ }^{42}$ In addition to conveying useful information, this conversation can also impress upon students that the professor cares about their educational experience and that the school as a whole wants them to succeed. Professors may, for example, discuss the school's academic support program or even introduce academic support professionals who are available for students. If the university has a writing center on its main campus, the professor may recommend their students visit it for assistance. Additionally, professors can share information about mental and physical health resources that are available. ${ }^{43}$ Some professors go as far as to

\footnotetext{
40 Schultz, supra note 38 , at 17.

${ }^{41} I d$. at 12-18 (discussing a survey, distributed by Schultz, of law professors about how they combat unprofessional behavior); $i d$. at 13-14 (relating to the first day of class, one respondent said "I tell my students on the first day of class that plagiarism is not acceptable. ... I also tell them on the first day that if they violate the plagiarism rule, the no research rule, or the do-your-own-work rule, I will give them a zero, refer them to the Dean for disciplinary action, and will also write a letter to the bar examiners saying that they have a problem following ethical rules. I know this sounds very harsh, and the students always blanch, but so far I haven't had any real problems. Being harsh up front seems to avoid difficulties later.").

42 Hess, supra note 37 , at 374.

43 Schultz, supra note 38 , at 17 ("Inform the student about the opportunities to get counseling.").
} 
explicitly offer themselves as resources for career advice, writing projects, and class recommendations.

The first day is the perfect time for professors to use the function of communicating mandatory information to inject their own priorities and availability. In this realm, Tina seems to fit the norm of what most professors do and what best practices suggest. She first reaches her students on a personal level through questions and the use of her first name, but she emphasizes the collaborative nature of her classroom, using administrative tasks to establish a theme that is important to her for the semester.

Professors can chip away at the nerves and icy formality of the traditional law school classroom in many other ways. The next section addresses some steps toward creating an effective learning atmosphere even on the first day of class.

\section{II}

\section{ESTABLISHING A SUPPORTIVE CLASSROOM ENVIRONMENT}

The first day of class sets the tone that either facilitates or hinders effective teaching and deep learning. ${ }^{44}$ Tina, like many conscientious professors, promotes interaction by greeting students as they enter the classroom, ${ }^{45}$ encouraging students to ask questions or otherwise talk during the first class, ${ }^{46}$ and being open to continuing the discussion after class.

\footnotetext{
44 DAVIS, supra note 10 , at 20.

45 My legal writing students' first introduction to me is a YouTube video of "Welcome to the Jungle" by Guns N' Roses. For the four or five minutes before every legal writing class I teach, the room is serenaded by an 80 s hair band. Why? No real reason other than that it gets some good energy in the classroom before we start. And over time, it's just become a "thing." The students know it's coming. It's always 80 s music. I take requests, but I keep the master list in my control. I tell them, "Dancing is permitted, if you'd like, and even a bit of mocking the 80 s hair if you must. But let's smile a bit, generate a good vibe, and let out some nervous energy before class."

46 Master educator Gerry Hess wrote about one fall semester:

Even after 14 years of teaching, I'm a bit nervous about my first classes. I think that a good way to deal with that is to be clear in my own mind about the goals of my first classes. ...

Convey excitement about the course

Have each student speak

Have students engage in course design

Convey respect for students

Have students feel that this will be different from a first-year course.
} 
The best practices literature emphasizes the importance of establishing a supportive classroom environment-one in which students can participate without derision and can comfortably request clarification or explication. ${ }^{47}$ Students thrive when they can openly grapple with new concepts, make mistakes, and demonstrate their newfound and sometimes fragile command of the material. Both the Best Practices Report ${ }^{48}$ and the Carnegie Report ${ }^{49}$ echo these priorities in calls for reforming and humanizing legal education. ${ }^{50}$

The logistics of developing a supportive classroom environment are many-faceted. Orderly, substantive, and positive exchanges between the students and professor form the core of an effective classroom experience. Particularly in law school, students refine their command of the material and test the boundaries of their understanding through discussions with their professor. That crucial student-teacher interaction depends largely upon the students' trust in the professor, the professor's obvious investment in the students, and a rapport that encourages participation on both sides.

I arrive early to beg two students to participate in a nonthreatening classroom exercise (and then I actually make it nonthreatening and semi-funny). I do this because I want the classroom to be a safe place and I want students to trust me. If they trust me, then they will be more likely to confess to me when they aren't understanding something we're discussing.

Students must be deeply invested in the course and the material to get the most out of the educational experience. In the rush to put forth

Content does not matter. My speaking needs to be less than $50 \%$ of the time. I want to convey some basic information about the course, but that is less important than the goals above. I want to begin making a positive connection with each student.

Gerald F. Hess, Learning to Think Like a Teacher: Reflective Journals for Legal Educators, 38 GoNZ. L. REV. 129, 142 n.86 (2003).

47 Sean Darling-Hammond \& Kristen Holmquist, Creating Wise Classrooms to Empower Diverse Law Students: Lessons in Pedagogy from Transformative Law Professors, 17 BERKELEY J. AFR. AM. L. \& POL'Y 47, 74 (2016) (“Transformative professors explained that one key to ensuring that students from all backgrounds learn content is to create a safe space where they are freed from distractions and can focus on learning.").

48 Roy StUCKey ET AL., Best PRACTICES FOR LEgAL EDUCATION (2007).

49 William M. Sullivan et al., EduCAting Lawyers: Preparation for the PROFESSION OF LAW (2007).

${ }^{50}$ Louis N. Schulze, Jr. \& Adam A. Ding, Alternative Justifications for Academic Support III: An Empirical Analysis of the Impact of Academic Support on Perceived Autonomy Support and Humanizing Law Schools, 38 OHIO N.U. L. REV. 999, 1013-14 (2012). 
the class procedures and policies, it can be easy to overlook the need to get students to buy in to the value of the course and the professor as their guide. The flipside is that if that investment is not achieved early on, students may never develop more than a passing commitment to the subject matter and the professor. The best practices literature provides a number of ways for professors to solicit student buy-in, beginning in their very first interactions. ${ }^{51}$

Demonstrating enthusiasm for the course and commitment to helping students learn is vital to getting buy-in from the students. ${ }^{52}$ This energy communicates to the students that the course is valuable and that the professor is the right person to be teaching it. Indeed, for many students, the professor's enthusiasm motivates their interest in the material and their attention to the class. This commitment is particularly palpable when the professor conveys a genuine interest in working with the students during the semester ${ }^{53}$ and makes it clear that she is willing to help the students understand how the course will serve their needs. ${ }^{54}$ The lesson here is simply to not be afraid to wear your heart on your sleeve to some extent.

51 See, e.g., First Day of Class Student Buy-In: Advice from Unknown Mentors, BELLARMINE UNIV., http://www.bellarmine.edu/docs/default-source/faculty-develop ment-docs/TLC_13_First_Day_of_Class_Student_Buy.pdf?sfvrsn=0 (last visited Mar. 25, 2017); Tim Slater, Get Better Student Buy-In Using a 'Negotiated Syllabus, 'SOCIETY FOR COLLEGE SCIENCE TEACHERS (Jan. 16, 2016), http://www.scst.org/blog/get-better-student -buy-in-using-a-negotiated-syllabus.

52 Qin Zhang, Instructor's Corner \#3: Teaching with Enthusiasm: Engaging Students, Sparking Curiosity, and Jumpstarting Motivation, 9 COMM. CURRENTS (2014), http://dev.natcom.org/CommCurrentsArticle.aspx?id=4678; Chris Palmer, Inspiring Enthusiasm and Motivation in the Classroom, AM. UNIV., http://www.american.edu/soc /faculty/upload/CTRL-Building-Student-Engagement-Handout.pdf (last visited Mar. 25, 2017). One lighter moment of the first class of my estates and trusts course is a brief period when I talk about why this is the best class they will ever take in law school. In part, it's designed to be humorous and lighthearted. In part, I want to try to capture the essence of the kinds of cases they will read. I also want to share my enthusiasm for what a wonderful course it will be, and I want them to look forward to the class. If they care for and enjoy the course, the classroom atmosphere will be better and everyone will benefit. And plus, if I keep telling them that it's the best course ever, eventually they will start to believe me, right?

53 Dunlap, supra note 13, at 407.

54 "On the first day of class, after reviewing the syllabus, I negotiated with the students about the course structure. I asked them to identify students' and instructors' interests in the course which I listed and projected on a screen in the front of the class." John M. Lande, Lessons from Teaching Students to Negotiate Like a Lawyer, 15 CARDOZO J. CONFLICT RESOL. 1, 12 (2013). In that way, professors can emphasize the skills and interests students find most important and reassure them that the course will achieve those goals. See id. at 13-14. 
Buy-in is particularly important for Tina's class because it involves significant student collaboration. She knows there is resistance to the collaborative nature of her class - both passive and aggressive - and she addresses it directly by including an interactive exercise in the first class.

I make class as interactive as possible to set the tone for the collaborative nature of the course. I have students work on an exercise in groups.

Giving students an opportunity to meet with each other on the first day of class $^{55}$ also enhances rapport and facilitates a sense of community. ${ }^{56}$ In smaller classes, engaged professors often divide students into groups to meet each other or plan an activity that provides students an opportunity to speak to one another and introduce themselves. ${ }^{57}$ In larger classes, professors can set the stage for community building by planning a collaborative exercise on the first day of class so that students meet at least a handful of their classmates. In upper-level courses at smaller law schools, it may not be necessary to introduce third year law students who have shared the same basic schedule for the past couple of years. ${ }^{58}$ Regardless, in each new class, students benefit from the early establishment of a safe

\footnotetext{
55 DAVIS, supra note 10, at 24.

56 Bryan Adamson et al., Can the Professor Come Out and Play?-Scholarship, Teaching, and Theories of Play, 58 J. LEGAL EDUC. 481, 514 (2008); see also Sophie M. Sparrow, Practicing Civility in the Legal Writing Course: Helping Law Students Learn Professionalism, 13 J. LEGAL WRITING INST. 113, 140-41 (2007) ("[O]n the first day of class this year I engaged students in a discussion about the kind of class environment that best served individual students' learning needs. Each student was asked to interview and then introduce a classmate, including one thing that was critical to creating an optimal learning environment. Within a few minutes, students had identified all the behaviors that I had previously required of them to earn full 'professional engagement' points, such as being flexible and open about others' views, being on time, being prepared, not dominating the discussion, contributing to a non-disruptive environment, participating in discussions, and sharing and being considerate of others' educational, personal, and cultural backgrounds. ... Rather than ending the discussion there, compiling a list of these "classroom guidelines," and asking students to adhere to them, I asked all students to propose appropriate consequences for not adhering to a given behavior, and who was responsible for implementing that consequence.").

57 Adamson et al., supra note 56, at 514 ("On the first day of class, do an exercise that requires that the students introduce themselves and get to know one another.").

58 I teach Decedents' Estates and Trusts, an upper-level class with an enrollment north of fifty students every semester. My first day of that course differs vastly from my first day in legal writing. No 80 s music, no brush-with-fame conversations, no get-to-know-you games. Upper level students don't necessarily need that kind of lead-in to feel comfortable in law school. Moreover, a larger class will have a less intimate feeling over the course of the semester, and that sense starts on the first day.
} 
setting in which they can begin to express their ideas with their professor and peers. With a familiar and comfortable environment, students will likely be more willing to speak up when they are struggling to keep up. Having collaborated with their peers from the first day, they are more likely to understand that they are not the only ones at sea and will feel less pressure to keep up the appearance of mastery.

Even with an environment that facilitates participation, professors may need to be more direct to elicit input on the class progression.

As I'm explaining material, I ask 'Did I explain that clearly?' rather than generally opening the floor for questions.

Here, Tina acknowledges that even after establishing a relaxed classroom environment, it can still be awkward to hold the class up for open volunteering of questions. Both approaches (asking whether the explanation was clear and opening the floor for questions) are trying to uncover confusion about the material. But in asking whether there are any questions, the professor subtly implies that the student is the problem, while in asking whether the explanation was clear, the onus of a student's understanding is on the professor. It's not a singledirectional information dump; it's a dynamic exchange between the professor and student. Both sides are ascertaining effective modes of communication and will need to work together to promote their mutual goals. But at the end of the day, it's not all about the material.

I bring homemade, fresh-baked, double-fudge brownies for the students to enjoy during the break.

Turns out, professors are human beings, complete with working ovens and access to supermarkets. Further, law students possess at least a few human traits, like enjoying sugary treats. Tina likes to bake and her students appreciate the personal touch and the boost of energy. Additionally, she wants her class to be fun and perhaps unexpected; she throws candy to students who give a correct answer or sometimes two pieces of candy to a student who gets the answer wrong, just for giving it a good try. It's part of having fun in Tina's course. ${ }^{59}$ Indeed, such acts of kindness can actually be not-so-

\footnotetext{
${ }^{59}$ Here is how it began: when Tina left practice to begin teaching, her then-five-yearold son seemed upset because he assumed that she would be working with kids. She explained that her students were grown-ups and then asked him if he wanted to come to class to meet the students. He said "Yes. I'll come at snack time." So Tina and her son
} 
randomly employed throughout the semester-when the class is fading or right after they've turned in a major assignment, for example. ${ }^{60}$ But especially on the first day, brownies preview and reinforce the caring, supportive personality Tina exudes throughout the semester. ${ }^{61}$

\section{III}

\section{SETTING COURSE EXPECTATIONS AND STANDARDS}

Whether it's deliberate or inadvertent, the first day of class will set the tone and expectations for how future classes will be conducted. With those stakes in mind, considerate educators evaluate which signals are of primary importance to communicate in the first class. ${ }^{62}$ Professors both implicitly and explicitly set expectations by the manner in which they run the initial class session. Starting and ending on time, for example, implicitly indicates to students that the class will meet in a consistent pattern, and more importantly, that the professor values their time and that they should reciprocate. The professor also implicitly models (and sets the tone of) professionalism by demonstrating meticulous preparation (not fumbling with books and notes, and transitioning smoothly from administrative tasks into the substantive material), dressing sharply, and addressing the students in a respectful way.

The first class period can also explicitly reveal the nature of the material and the challenge it may present to students. In Tina's words:

brought chocolate chip cookies and juice packs to class. The students loved it, and it became a regular part of her classes.

60 Or even better, as they're completing their student evaluation forms: "Why are Grant's evals always smeared with chocolate?"

61 Indeed, Tina told me that she uses candy when she guest lectures in other courses, even if not on the first day. Guest-lecturing, she maintains, is akin to being a substitute teacher, and the students are unforgiving.

As I get settled at the front of the room at the beginning of class, I open my bag and pour all types of chocolate candy from it. I announce that a student gets one candy for answering a question and two for asking. $1 \mathrm{Ls}$ seem particularly afraid of appearing unknowing, which is why a question gets a double reward. Because the classrooms are so large, I need to throw the candies to students. My throws conform to the stereotype. I throw like a girl. That just makes the class funnier because everyone starts laughing every time a throw ends up some place it shouldn't be.

62 See Angela McCaffrey, Hamline University School of Law Clinics: Teaching Students to Become Ethical and Competent Lawyers for Twenty-Five Years, 24 HAMLINE J. PUB. L. \& POL'Y 1, 37 (2002); see also Gary Monserud, An Essay on Teaching Contracts and Commercial Law for the First Time (Even If You Have Taught These Courses Many Times Before), 82 N.D. L. REV. 113, 129 (2006). 
The material is difficult. It may be a struggle. You're not expected to get it on the first try. In fact, you will see this material multiple times throughout the semester.

That message, combined with Tina reiterating her office hours and availability, serves as an encouragement of sorts. Law student trepidation is widely documented, and Tina's supportive admonition gives students confidence to stick with a course that feels, and may in fact be, difficult. ${ }^{63}$ Tina explicitly reassures her students that even if the material seems impossible now, she is available to help them, and they will get through the course together.

Additionally, professors can generate goodwill and give some sense of security by providing students with strategies for approaching the course material. ${ }^{64}$ Professors can suggest useful study aids or encourage students to seek out help if they don't understand a particular piece of the course on which future course sessions depend. Giving students an estimation of how much time they should spend working on particular aspects of the course can also more clearly define expectations. Many professors include this information in the discussion of the syllabus by identifying certain projects that may be time-intensive and by highlighting various due dates. Through this dialogue, students can better anticipate their obligations and begin to strategize how to manage their other school, work, and personal commitments. Again, this conversation conveys respect for students' time and an understanding that they have responsibilities outside of this particular class.

\footnotetext{
63 Professor David Wilkins of Harvard University

acknowledges [students'] fear on the first day of law school and he has weekly lunches with them so that he can "get to know something about [them] . . not just how [they] perform on a test." As an antidote to students' hyper-focus on grades, he tells them that "grades are not the measure of you." These rather simple acknowledgements that students are humans, not an LSAT score or civil procedure exam grade, are obviously humanizing, as they show respect for the students' perspectives and honor intrinsic, not extrinsic values and motivation.
}

Dunlap, supra note 13, at 409-10.

64 See DAVIS, supra note 10, at 26. For example, professors who plan to use pure policy questions on their final exams may wish to inform their students of this on the first day. These types of questions require the students to study differently and students must plan accordingly. Professors can use the first day to be as straightforward and honest as possible about expectations of students for the exam and other areas of the class. See Russell L. Weaver, Langdell's Legacy: Living with the Case Method, 36 VILL. L. REV. 517, 589 (1991) 
Not surprisingly, best practices research supports explicitly defining expectations for student participation throughout the semester $^{65}$ and about how class time will be spent. ${ }^{66}$ Those expectations may vary widely depending upon the type and level of course. The range of student participation includes collaborative work, volunteering for classroom discussion, answering cold-call questions, or any combination. Although students will eventually ascertain the professor's desired participation level, there is no substitute for clearly stating expectations regarding manner and content of classroom interaction from the beginning.

I announce that most classwork will be collaborative, including graded assignments. And I explain that virtually everything in the real world of attorneys is done collaboratively, so this is a skill they need to learn.

Another suggestion for setting course expectations from the best practices literature is to have students participate in a group exercise (for classes that will be collaborative in nature) or to work through a case or other piece of material that demonstrates the course content. ${ }^{67}$ In that way, professors can begin teaching students how to participate in the class and give them an idea of how the remainder of the course will unfold. ${ }^{68}$

\footnotetext{
65 For example:

On the first day of the semester [one professor] explains to the class that each student will be "on panel" for one day during the semester, and that each will be told ahead of time when that day will come. Throughout the semester she calls on those students who are on panel for that day and leads them through a discussion of the case or issue assigned for class. Afterwards, she opens up the discussion to the entire class.
}

Orin S. Kerr, The Decline of the Socratic Method at Harvard, 78 NEB. L. REv. 113, 125 (1999).

66 See DAVIS, supra note 10 , at 26. Professors who wish to have a collaborative learning environment throughout the semester could use the first class period to organize the students into small "law firms" who will be on call together throughout the rest of the semester. Robert P. Schuwerk, The Law Professor as Fiduciary: What Duties Do We Owe to our Students, 45 S. TEX. L. REV. 753, 791 (2003).

67 DAVIS, supra note 10, at 26.

68 One key part of my estates and trusts syllabus that I emphasize is the writing focus and why it's such a big component of the class. I want students to understand that it is part of the course's pedagogical strategy. To do this, I use the logistical aspects of the writing assignments as a hook. Administratively, I need to explain how and when they'll receive and turn in their weekly writing assignments. But in doing so, I use that opportunity to talk about why we're doing those assignments and my belief that, in addition to casebook knowledge, they need to develop practical lawyering skills in estates and trusts. 
During the first class, I have students work collaboratively in groups on a difficult exercise. While they're working, I walk around the room and stop to help each of the groups.

In addition to explicitly telling the students that much of their work will be collaborative, Tina demonstrates to the students the benefits of collaboration with this first day exercise. Many students come to law school with a preexisting animus to collaboration because they fear that other group members will not fully participate, which will result in a lower grade for the entire group. As soon as possible, Tina wants them to see the advantages of working together.

Assigning a difficult task for this exercise drives home Tina's point, while at the same time reinforcing her earlier message that the course material will be challenging. In addition, through the collaborative exercise, students will see the benefits of having their ideas challenged and challenging ideas of other students. They will see that the collaborative process results in a better answer than any one individual's answer. Moreover, the student interaction results in the students exploring out loud the legal concept more extensively than if the students had worked on the exercise solo-almost semipassively.

A crucial aspect to this classroom exercise is Tina's movement around the classroom.

The idea is to give them confidence in the course. It's not just that students are collaborating with each other, but that I am collaborating with them in their learning.

Her presence while students are working puts into action what she has told them before - that she is available and willing to help. More specifically, she is not just going to wait around until they have finished the exercise (probably incorrectly, in her words) to offer guidance. Instead, she assists them as they're working on the problem so that they can apply her suggestions to the remainder of the exercise - in that way deepening their learning.

In addition to an in-class exercise to begin substantive course work, some kind of diagnostic test during the first class period ${ }^{69}$ can also

${ }^{69}$ DAVIS, supra note 10 , at 26; Cordon, supra note 34 , at 411 ("On the first day of class, I assign students a research project and give them a certain amount of time (usually three hours) to complete it. The students' performance on this assignment serves as a benchmark for students to gauge their progress during the course. In a task-mastery motivational system, students are not judged in terms of how they relate to one another, so 
help set expectations by providing a glimpse into the understanding students have of the material and what topics may necessitate additional review. ${ }^{70}$ A sample ungraded exam question on the first day may similarly reveal to professors and students any misconceptions or other glaring gaps in the students' background in the basic subject matter. ${ }^{71}$

Tina waits until the second class period to emphasize a different but equally important aspect of her professorial personality:

The exercise students have to do for the second class plays off of the first day's exercise in that it reinforces the benefits of collaboration. It also establishes my high expectations for their work over the course of the semester. Day One says I'm trustworthy and collaborative. Day Two says I have high standards and students better not blow me off.

The interplay between the first and second classes, usually within the same week, can be a powerful way to drive home your expectations for the class. A few days before the second class, students e-mail Tina a list of their personal "Top Ten Rules" for drafting a preamble to a contract, given the reading and class discussion from the first day. She responds promptly by e-mail, commenting on one or two deficiencies in the lists she receives. In this way, Tina establishes almost immediately that she's evaluating the students' efforts and will provide feedback, that mediocrity is not sufficient, and that she has high standards for student work product.

But Tina also uses the "Top Ten Rules" to reinforce the usefulness of collaboration that students saw in the first class. An in-class exercise for the second day of class asks students to draft a preamble, using only their lists of "Top Ten Rules." While working together on the assignment, the students quickly realize that drafting a legally

it is important to stress that student performance on this benchmark assignment will not be judged in relation to other students.").

70 Margaret Butler, Resource-Based Learning and Course Design: A Brief Theoretical Overview and Practical Suggestions, 104 LAW. LIBR. J. 219, 242 (2012) (“A preliminary assessment, given to students before class begins or on the first day of class, offers several benefits. The assessment results can help an instructor plan the amount of time necessary to adequately address required topics. It may also help an instructor identify students who would be able to explain . . . concepts or . . . resources to other students. Students, upon realizing the depth of their ignorance, may be more motivated to actively participate in a course.”). For example, some writing professors are now using Core Grammar on the first day of class, or even before, to assess students' basic grammar comprehension.

71 Exposing them to a particularly draconian exam question may also drive students in lemur-like herds to the registrar's office to drop your class, so use appropriate caution when selecting your samples. 
sound preamble on their own would be nearly impossible. But working collaboratively with a group, students can create a solid work product. In this way, the second class continues to set the tone for the semester and reinforces the benefits of collaboration, an important component for the course.

\section{IV}

\section{PREPARING FOR THE FIRST DAY}

A smooth first day sets your identity in the classroom, and any later inconsistency is assumed an aberration. It is therefore worth carefully thinking through that first interaction well in advance, because addressing a room full of law students takes some preparation, both mental and otherwise. In addition to developing a game plan similar to Tina's for managing the in-class experience, some preparation in other categories can help to ensure a smooth rollout of the new course. This section deviates beyond Tina's advice for the first class but offers suggestions for laying the foundation to implement her strategies.

There is a surprising amount of paperwork involved in conducting a class: rosters, sign-in sheets, hard copies of any handouts such as the syllabus or supplemental readings, etc. Getting that paperwork in order is an essential step to avoiding a panicked run to the printer in moments prior to the initial session. Even those with years of teaching experience can benefit from the orientation provided by reviewing syllabus and the table of contents of the textbook again. This review serves as a reminder of where the course is going and brings the big picture into mind from the start. These little things add up, so it is best not to save them for the hour or two before class.

Students notice technological hiccups. If the new semester's classroom is unfamiliar, a quick physical inspection and run-through can prevent awkward fumbling with PowerPoint screens, audio clips, and dry erase markers. ${ }^{72}$ Even those who are classroom savvy benefit from rehearsing their interaction with the classroom. It has likely been weeks or months since the last time a professor stood in front of the classroom, and it helps to scout out everything from standing position to workable locations for lecture notes and water. ${ }^{73}$

\footnotetext{
72 It is worth noting that regardless of how much preparation you do and its proximity to class time, the PowerPoint, projector, computer, USB drive, or any combination of the foregoing will fail in a catastrophic and unpredictable way.

73 Or Diet Coke.
} 
Perhaps more important to a successful first day of class, however, is the mental preparation. As repeated throughout this Article, a comfortable classroom environment ensures that students learn better and enjoy the experience. To create that atmosphere, it is necessary for the professor to be comfortable in the front of the room and to remember why this class of law students should entrust their education to her. For newly minted professors, it is helpful to remember the path to this position of authority, including the years developing subject matter expertise. ${ }^{74}$ Recalling this path and expertise can help eliminate the tendency to become uneasy or even defensive in the face of challenging questions from the students. With that attitude in mind, professors can enter the classroom confident and comfortable, knowing that they belong there without having to explicitly say so or demand respect for authority.

\section{CONCLUSION}

The first class meeting can be nerve-wracking for law professors and students alike. The fear and nervous energy are present whether one has been teaching for a day or a decade. Teachers must set the tone and expectations of the classroom, yet accommodate the organic development of a unique class identity and encourage collaboration among students. With these high stakes, it is no small wonder that professors can devote an inordinate and seemingly disproportionate time preparing for that first day. The first class sets the stage. It serves as the opening act that foretells almost all about how the play ends.

Unfortunately, there is no magic formula for establishing rapport and student engagement in the classroom. Experienced professors often pass on tricks of the trade, and best practices research can provide additional guidance. But all professors must find their own delivery, pace, structures, and methods that allow them to effectively and comfortably communicate with their students. Tina's suggestions, accumulated over years of teaching, provide a template for structuring the first class. Naturally, it is a highly individual process that involves

\footnotetext{
74 Why am I at the front of the classroom? Because I excelled at a highly regarded law school. Because I'm smart. Because I can learn and process new material faster than the average bear. Because I'm a good teacher and can convey new information to laypeople in a way that helps them internalize it. Because I can manage a classroom and employ innovative and effective teaching practices to help students learn. Because I sincerely care about the material and the students' successful mastery of it. Make no mistake - these are not things I ever tell my students. They are the things I keep hidden in my pocket to remind myself about why I have this job, why I'm good at this job, and why I'm qualified to do it.
} 
personal honing over time. As with most things in law teaching, being deliberate and methodical about what to accomplish in the first class period can pay dividends throughout the semester. 
